\title{
セリウムから始まり光学活性 ホスフィンの化学へ
}

今本 恒雄

Tsuneo Imamoto

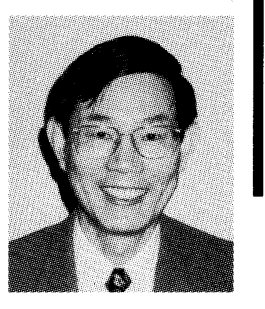

1980 年 4 月, 自分の年齢をまともに言うことに恥ず かしさを感じる歳になっていたが, やっと大学の助手に 採用していただいた。それより 7 年前に大阪大学で助手 を勤めさせていただいたが, 男のロマンを求めて妻子を つれてアメリカに渡った。しかし, 夢と現実の開きは大 きく, かつ自分の能力不足も相まって, 再びアカデミッ クポジションを得ることは著しく困難であった。それた けに, 辛うじて得たチャンスを最大限に生かし, 何とし てでも研究成果をあげたいと念じていた。元気で仕事に 打ち込み，何かひとつ結果を出すことができれば，それ が随分と扔世話になった師への恩返しになる。

当時は元素の特性を生かした新しい有機反応や手法の 開発が合成化学における重要な課題の1つであった。す なわち, 多くの有機化学者がそれぞれの元素のユニーク な特性の発掘とその合成化学への利用について競って研 究を行っており, その様子は, まさに周期表に広がる燎 原の火の如くであった。自分も何か 1 つの元素で花を咲 かせたいという思いは日々募り, そのために, まだ合成 化学者があまり手をつけていない元素を探した。その結 果, 希土類元素が目に留まった。これらの元素は通常周 期表の欄外に載せられており, 多くの “主流に属する元 素”とは異なり，いわば “異端の元素”にも見えた。希 土類元素をこのようにみたとき, ふと自分自身もはみ出 し者であることに気づき，一層これらの元素に対する親 近感が湧いたものである。

実際の研究は，セリウムを用いることから始まった。 なぜなら，セリウムは希土類の中で最も天然存在量が多 く，比較的安価に入手できるためである。最初にセりウ ム金属の塊を購入して, Barbier 型の反応を試みた。セ リウムは摩擦により容易に発火する金属であるため, イ ンゴットを削って反応に用いる粉末を得るのも容易では なかった。何回かの試行錯誤の末，ようやく式 1 の反応 を行うことができ, 千葉大学へ赴任して最初の報文を出 すことができた ${ }^{1}$ 。これは研究のイニシャチブをとるた
めに書いたわずか 2 ページのささやかな報告であるが, 後日オリジナリティのある方法という内容で我々の報文 を紹介した記事を見た時，世の中には必ずどこかで見て いる人がいるものだと実感した。

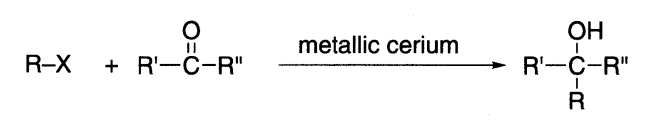

このセリウムを用いる研究は, 塩化セリウムを用いる 方法へと展開した。カルボニル化合物と Grignard 試剤 あるいはアルキルリチウムと反応させてアルコール類を 得る反応は最も重要な炭素-炭素結合形成反応の 1 つで あり, どの有機化学の教科書にも書かれている。しか し，教科書どおりに反応するとは限らず，エノール化， 還元, 共役付加等のいわゆる異常反応が起こり, 目的の 生成物が収率よく得られない場合がある。このような場 合に, 塩化セリウム存在下で反応させると, 異常反応が 抑制されて，正常付加物が高収率で得られることを見い だした $(\text { 式 } 2)^{2,3)}$ 。従来の方法では目的物の収率がわず か数パーセント程度の反応が, 塩化セリウムを用いると 飛躍的に $90 \%$ 位まで向上したとき, 研究の手ごたえを 実感するとともに，この手法はやがて多くの人に使われ るであろうと思ったものである。

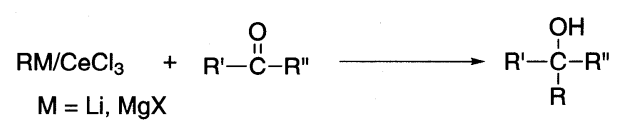

一方, 現在も行っているホスフィン・ボランに関する 研究は, 大きな構想をもって始めたものではなく, 偶然 の出来事がきっかけとなって開始された。先に述べたよ うに，塩化セリウムの合成反応への利用について検討し ている過程で, ホスフィンオキシドと水素化リチウムア ルミニウムー水素化ホウ素ナトリウム-塩化セリウム系試 郕を反応させるとホスフィン・ボランが高収率で生成す 
ることを見いだした $(\text { 式 } 3)^{4)}$ 。

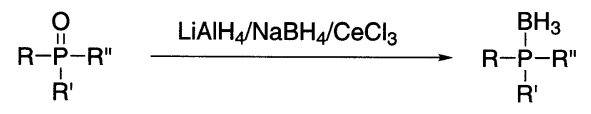

この時, 実験を行ってくれた楠本哲生君とともに感激 したものである。今にして思えば, 私の勉強不足, 知識 不足だからこそ興奮したとも言えるが，我々にとって予 期せぬ反応が起ったことと，ホスフィン・ボランがその 構造から予想されるよりもはるかに安定であることに驚 いた。調べてみると，ホスフィン・ボランは既知化合物 ではあったが, 有機化学の観点からはほとんど研究され ていなかった。それゆえにホスフィン・ボランは我々の 研究対象にふさわしく，その後種々の誘導体を合成する とともに反応性について調べた。あるとき，ホスフィ ン・ボランとアミンを反応させると, ボラナート基 $\left(\mathrm{BH}_{3}\right)$ がアミン・ボランとなってはずれ, ホスフィンが ほとんど定量的生成することを見つけた。直ちに, 光学 活性ホスフィン・ボランを合成し, その立体化学につい て調べてみると，100\% 立体保持で反応が進行すること がわかった(式 4$)$ 。

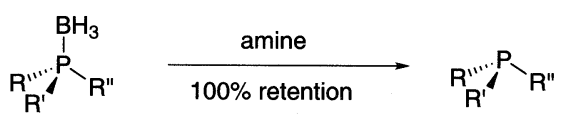

この反応は単純で当たり前に見えるが, 私はこの発見 に興奮した。その理由の 1 つのは，この反応とそれまで に我々が開発したホスフィン・ボラン誘導体の合成法を 組み合わせれば, リン原子上に不斉中心をもつ光学的に 純粋なホスフィンの合成が可能になると直観的に感じた

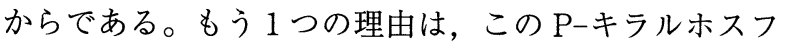
インの合成反応のなかで, ボラナート基がユニークな役 割を演じていることに気がついたからである。すなわ ち, ボラナート基は親電子試剤と反応しやすいホスフィ ンを保護していると同時に, リン原子に結合している置 換基からの脱プロトン化を容易にさせる活性化の役割を 果しているのである。リン原子上の “ $\mathrm{BH}_{3}$ ”を“保護と 活性化”という自分なりの考え方で捉えることができた のが，非常に嬉しかった。

もうひとつ, 興奮と感動を味わったことについてを述 べたい。これは予想外のことが起きた時の驚きではな く, 狙いを定めて行った研究がうまくいった場合の喜び である。良く知られているように光学活性ホスフィン は, 触媒的不斉合成に用いられる錯体の不斉配位子とし て重要な役割を果している。それゆえに, 光学活性有機 リン化合物を扱っている者として，真に有用な配位子を 是非自分達の手で世の中に提供したいと思っていた。
我々が設計したものは，後にBisP*と略称をつけたジホ スフィンである。

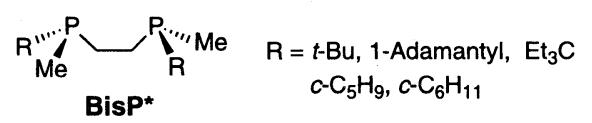

この配位子は，リン原子上に最もかさの小さいメチル 基とかさの大きいアルキルをもっている $C_{2}$ 対称の $\mathrm{P}-$ キ ラルトリアルキルジホスフィンである。分子の骨格は極 めてシンプルであるが，これで実用的レベルに達する不 斉誘導が起るものと考えていた。BisP*の合成は，ホス フィン・ボランを用いることにより，三塩化リンから 3 工程で達成するこ。とができた $(\text { スキーム } 1)^{5)}$ 。
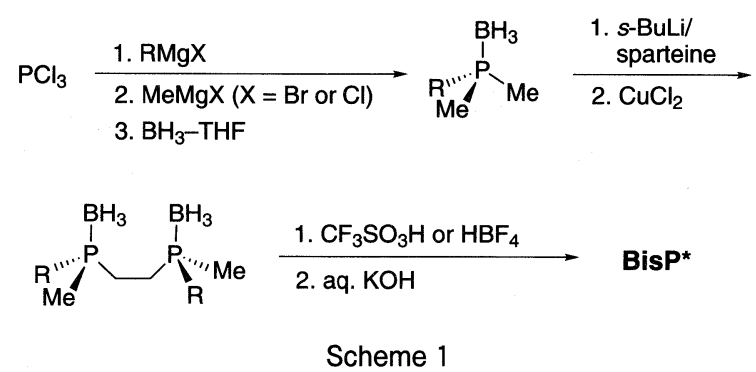

その触媒的不斉能は, 最初に $t-\mathrm{Bu}-\mathrm{Bis} \mathrm{P}^{*}$ のロジウム 錯体を用いてデヒドロアミノ酸の水素化で試された。常 法に従って反応系を水素置換した後, 水素圧を示すゲー ジを見つめた。 3 時間位経っても, 圧力を示す針は動か ず，反応しているようには見えなかった。わずかでも反 応していれば何か情報が得られるのではないかと思い, 反応液を HPLC に打ち込んだところ，大きなピークが 1 本現れた。このピークが原料によるものではなく, 還 元生成物の一方のエナンチオマーによることが分かるの に，それほど時間を要さなかった。触媒活性は予想して いたよりも大きく，系内を水素で置換している最中に反 応が完結し，その不斉選択性は $99.5 \%$ 以上であったの である。

我々はこの研究結果を踏まえて, さらに単純な構造を もつ配位子の合成に挑むことにした。標的配位子は $\mathrm{P}-$ キラルホスフィノメタン（後に MiniPHOS(ミニホス) と命名）であり, 当時大学院博士課程の学生であった山 野井慶徳君がこの種の配位子 4 つの合成を精力的に行っ てくれだ)。それらのロジウム錯体の 1 つである $\left(\left[\mathrm{Rh}((R, R)-t-\mathrm{Bu}-\mathrm{MiniPHOS})_{2}\right]^{+} \mathrm{PF}_{6}{ }^{-}\right)$の単結晶 $\mathrm{X}$ 線解析 を行ったところ, 図 1 に示す ORTEPが得られた。剛直 な 4 員環構造とともに, 第 2 および第 4 象限がかさ高い $t$-ブチル基で遮蔽された理想的な不斉空間が形成されて おり，非常に高い不斉選択性の発現を予期するもので あった。早速, この錯体を用いて数種類のデヒドロアミ 
ノ酸の不斉水素化を行ったところ, 反応性は BisP*と比 較して若干劣るものの, 基質によっては $99.9 \%$ 以上の不 斉選択性が得られた。また, $i$-Pr-MiniPHOS の錯体を 用いた場合には，その配位子の分子量がわずか 192 であ るにもかかわらず，不斉選択性は $98 \%$ に達した。メチ ル基とイソプロピルの違いだけで，これほど大きな不斉 選択性が発現したことに，大いに驚いたものである。
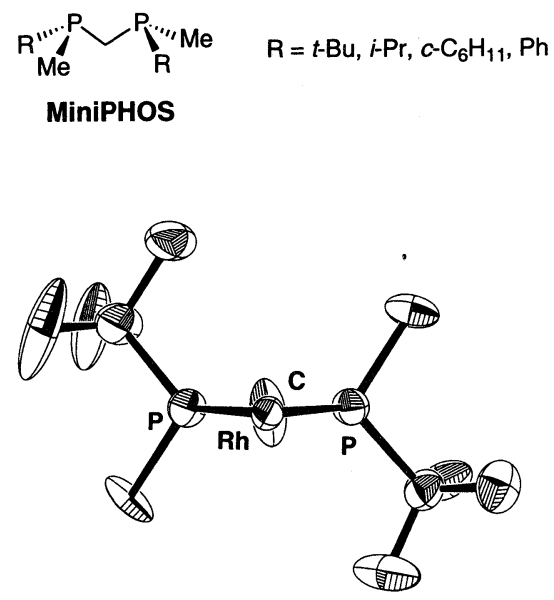

Fig.1 An ORTEP drawing of $\left[\mathrm{Rh}((R, R)-t \text {-Bu-MiniPHOS })_{2}\right]^{+}$ $\mathrm{PF}_{6}{ }^{-}$. The $\mathrm{PF}_{6}{ }^{-}$anion, hydrogen atoms, and one $t^{-}$ $\mathrm{Bu}-\mathrm{MiniPHOS}$ are omitted for clarity.

これらはほぼ計画どおりに進んだ研究であるが，胸が どきどきする瞬間が何回かあった。その都度, 共同研究 者である学生と共に, 喜びを分かち合ったものである。

以上, 自分の体験の中から, 興奮と感動したことにつ いて述べた。これらは優秀な共同研究者と運に恵まれた お陰である。しかしながら，途中で放棄した研究もいく つかある。先を越されたためである。悔しくもあり, 共
同研究者に申し訳ないことをしてしまったと思う。作戦 を誤ったのが主な原因で, 安易な妥協, 遠慮, 詰めの甘 さなども敗因としてあげられる。「学問・研究は，その 実践においては，闘争である」という言葉を念頭におい て，一歩の踏み込みを怠らず，徹底的にやらなければ， 大きな興奮や感動をそう簡単には味わえないと思うしだ いである。

\section{文 献}

1) T. Imamoto, Y. Hatanaka, Y. Tawarayama, M. Yokoyama, Tetrahedron Lett., 22, 4987 (1981)

2) T. Imamoto, T. Kusumoto, T. Tawarayama, Y. Sugiura, T. Mita, Y. Hatanaka, Y. Yokoyama, J. Org. Chem., 49, 3904 (1984)

3) T. Imamoto, N. Takiyama, K. Nakamura, T. Hatajima, Y. Kamiya, J. Am. Chem. Soc., 111, 4392 (1989)

4) T. Imamoto, T. Kusumoto, N. Suzuki, K. Sato, J. Am. Chem. Soc., 107, 5301 (1985)

5) T. Imamoto, J. Watanabe, Y. Wada, H. Masuda, H. Yamada, H. Tsuruta, S. Matsukawa, K. Yamaguchi, J. Am. Chem. Soc., 120, 1635 (1998)

6) Y. Yamanoi, T. Iwamoto, J. Org. Chem., 64, 2988(1999)

(2000 年 1 月 31 日受理)

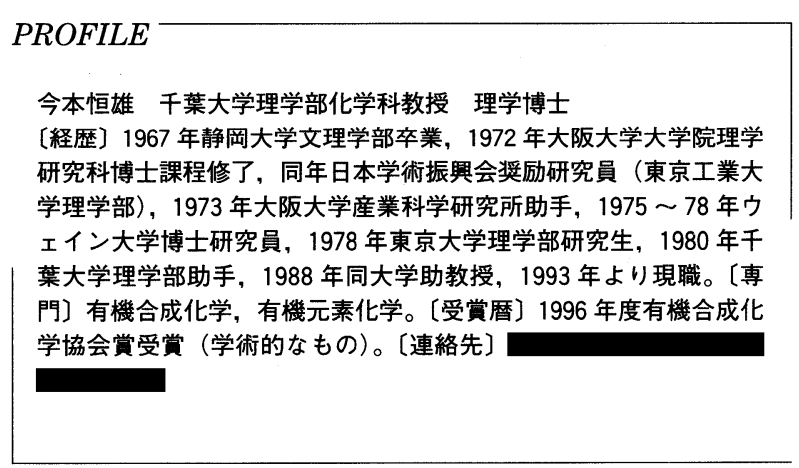

